\title{
The Holocaust and the Modernization of Gender: A Historiographical Essay
}

\author{
Ann Taylor Allen
}

$\mathrm{Z}$

YGMUNT Bauman's book, Modemity and the Holocaust, argues that the Holocaust was not an aberration from modernity, but rather the most extreme symptom of a distinctively modern pathology. ${ }^{1}$ Women are conspicuously absent from this indictment of modernity; Bauman, a sociologist, mentions neither gender as an issue nor women as individuals. This gap in Bauman's text is in fact full of meaning, for the absence of women as persons does not preclude the hidden presence of gender as a category of analysis. I shall use the absence and presence of gender in Bauman's text as a starting point for an examination of the historiography of women and gender and its relevance for our understanding of the Holocaust. First, I will tease out the hidden, gendered implications of Bauman's theory; second, I will look at the ways in which recent feminist scholarship has approached the question of women's responsibility for the Holocaust. Finally, I shall suggest that a consideration of the cultural construction of gender, as explored by recent scholarship in many fields, is necessary to our understanding of the historical and ethical concerns that Bauman and others have raised. I will bracket the important question of whether considerations of instrumental rationality were, as Bauman implies, the chief or exclusive justification for Nazi decision-making; for Bauman's emphasis on the bureaucratic mentality, even if one-sided, certainly points up an aspect of the Holocaust which sets it apart from the other great massacres of history. This essay concerns chiefly women's roles as perpetrators or bystanders. Thus references to "women," when not otherwise identified, are to women of the elite, or "German" ethnic group. ${ }^{2}$

1. Zygmunt Bauman, Modernity and the Holocaust (Ithaca, New York: 1989).

2. "German" is placed in quotation marks because it denotes the category defined by the National Socialists, who placed Jewish and other women of minority groups outside the national community. Of course, many of the women so excluded were, in fact, German citizens.

Central European History, vol. 30, no. 3, 1997, 349-364 


\section{THE HOLOCAUST \& THE MODERNIZATION OF GENDER}

This argument will employ a broad definition of "gender" that assumes that the differences between men and woman are primarily based not on biology, but on cultural construction. Such constructions of gender, along with other forms of difference-such as class, racial, religious, or national differences-shape our ways of thinking about human relationships, though often in unacknowledged ways. Conceptions of gender difference are integral to the organization of power, whether enacted through legislation and precept or symbolically represented through ideology. ${ }^{3}$

In order to understand the gendered implications of Bauman's theory, it is necessary to place it in the context of the sociological and historiographical tradition to which it belongs. Bauman's argument is by no means new, but was originated by the Frankfurt School during the 1930 s and 1940 s on a theoretical basis created by Max Weber. Although Bauman criticizes the Frankfurt School for emphasizing psychological rather than sociological causation, in fact his view of the relationship of modernity to totalitarianism in many ways resembles theirs. ${ }^{4}$ The Frankfurt School, and particularly its most prominent exponents, Theodor Adorno and Max Horkheimer, traced the sickness of modernity to a split in Enlightenment thinking between normative (or what Max Weber called "value") rationality, oriented toward the intrinsic value of ends, and instrumental rationality, directed toward objective and value-free efficiency in the realization of ends but incapable of normative judgment. In their collective work, Dialectic of Enlightenment, Adorno and Horkheimer characterize the tradition of "critical reason" (a recasting of Weber's "value rationality") as the most precious heritage of the Enlightenment and its submergence by a calculating and morally neutral instrumental rationality as the precondition for the entire failure of Western intellectual traditions to offer a basis for effective resistance to fascism. ${ }^{5}$ For Bauman, the Holocaust shows the ultimate consequences of a "culture of instrumental rationality" which combined enormous efficiency in the contrivance of technological and bureaucratic means with a cold indifference to the morality of the ends thus attained. ${ }^{6}$

In his essay, "Authority and the Family," Horkheimer connects this fateful split in the Western psyche to the history of gender relations, as he understood it. He sees one important precondition in the separation (usually traced by historians to the late eighteenth century) of private and public spheres: the first identified with the intrinsic value of human indi-

3. Cf. Joan Scott, "Gender: A Useful Category of Historical Analysis," American Historical Review 91 (December, 1986), reprinted in Joan Wallach Scort, ed., Feminism and History (New York 1996), 152-82.

4. Bauman, Modernity, 153.

5. Max Horkheimer and Theodor W. Adorno, Dialectic of Enlightenment, trans. John Cumming (New York, 1995; original edition New York, 1944), 3-6 and passim.

6. Bauman, Modernity, 107-16. 
viduals, loving commitment, and women; the second with the subordination of persons to impersonal ends, emotional distancing, and men. ${ }^{7}$ Horkheimer explains how the hierarchical relationship of these spheres, in which public concerns were valued over private concerns (for Hegel, the individual as family member was an "unreal and insubstantial shadow" and only as citizen "real and substantial") contributed to the prevalence of instrumental thinking in Western culture. ${ }^{8}$ In the family, and specifically within what he called the "maternal aura"-that is, in the female sphereHorkheimer perceives a potential locus of normative rationality, where "the individual always had the possibility of living not as a mere function but as a human being." Thus in theory the experience of maternal love could be the basis for resistance to the "culture of instrumental rationality," for "in the yearning of many adults for the paradise of their childhood... there are ideas and forces at work which ... in the bourgeois system of life rarely have any place but the family where they can survive at all."

Horkheimer's recognition of the connections between gender relations and politics, especially through the construction of public and private spheres, was in many ways pioneering. But his conceptual possibilities were limited by his evident inability to imagine women as historical actors. Because he does not constitute the mother as a subject, but only as a symbolic figure haunting her adult son's nostalgic "dreams of a better condition for mankind," the values which he calls "maternal" in the modern, public world. In fact, he takes a pessimistic view of the future, which he believes can only bring the further disempowerment of the nurturing mother by the authority of the father and of the state. Horkheimer's basically Marxist view of history, which identifies the overthrow of the female power exercised through a prehistoric matriarchy (in the words of Engels, "the worldhistorical defeat of the female sex") as the beginning of history, acknowledges no possibility of women's exercising public power in historic time. ${ }^{11}$ Women, while they remain in the female sphere, are thus endowed with innocence of the crimes of the modern state, but at the price of being placed outside modernity, and indeed outside of history itself.

7. Max Horkheimer, "Authority and the Family," in Critical Theory: Selected Essays, trans. Matthew J. O'Connell et al. (New York, 1972), 116-28.

8. G. W. F. Hegel, Phenomenology of Mind, 2 vols., translated and with an introduction by J. B. Baillie (London, 1910), 2:445.

9. Horkheimer, "Authority," 114. I am greatly indebted to Mechthild Rumpf, "Mystical Aura: Imagination and Reality of the 'Maternal' in Horkheimer's Writings," in On Max Horkheimer: New Perspectives, ed. Seyla Benhabib, Wolfgang Bonss, and John McCole (Cambridge, Mass., 1993), 309-34.

10. Ibid., 114.

11. Ibid., 118. 


\section{THE HOLOCAUST $\mathscr{E}$ THE MODERNIZATION OF GENDER}

Like Horkheimer, Bauman places the development of the "culture of instrumental rationality" in the context of the history of Western civilization. His first chapters discuss many aspects of this history, including racism, anti-Semitism, and the rise of scientific thinking, but make no mention of gender relations among these causative factors. This negligence is all the more striking in view of the year of the book's publication, 1989, when a substantial body of contemporary historical and sociological literature on the development of the gendered division of labor and of the relationship of public to private spheres existed. ${ }^{12}$

Bauman confronts the same problem as Horkheimer: given that Western culture is, as he contends, totally pervaded by the spirit of instrumental rationality, where is the locus of normative rationality from which this culture may be judged? In place of Horkheimer's theory of the "maternal aura," Bauman cites the highly abstract, complex, and poetic vision of the philosopher Emanuel Lévinas, whose ideas have inspired much postmodern ethical and philosophical inquiry. Starting in the 1960s, Lévinas criticized the Western tradition of ontology (especially as developed by Heidegger) for its subsumption of all beings under universalizing categories, thus denying the uniqueness of the human individual. Such philosophical systems, Lévinas charged, justified the sacrifice of the individual to aims claiming universal validity, such as those of a movement or statea clear reference to the recent history both of the Nazi and the Stalinist regimes. As an alternative to such destructive uses of reason, Lévinas asserted that ontology must yield its primacy in Western philosophy to ethics. The new ethical consciousness must affirm the transcendent value of the human individual through face-to-face confrontation and absolute responsibility. Such responsibility, which cannot be defined or limited by abstract definitions of individual rights, destabilizes the autonomy of the ego-traditionally among the highest values of modern Western ethicsby denying the separateness of the self from the other. "The absolutely Other is the human Other. And the putting into question of the Same by the Other is a summons to respond. The I is not simply conscious of this necessity to respond ... rather the $I$ is, by its very position, responsibility through and through."13

12. For example: Karin Hausen, "Die Polarisierung der Geschlechtscharaktere--Eine Spiegelung der Dissoziation von Erwerbs- und Familienleben," in Sozialgeschichte der Familie in der Neuzeit Europas, ed. Werner Conze (Stuttgart, 1976), 363-93; Seyla Benhabib and Drucilla Cornell, eds., Feminism as Critique (Minneapolis, 1987). The latter collection contains responses to critical theory by a group of feminist sociologists, philosophers, and political theorists, some of whom are widely published elsewhere.

13. Emmanuel Lévinas, "Transcendence and Height," in Emmanuel Lévinas: Basic Philosophical Writings, ed. Adriaan T. Peperzak, Simon Critchley, and Robert Bernasconi (Bloomington, Indiana, 1996), 17. 
Bauman takes Lévinas's ethic of absolute responsibility as the basis of normative rationality, but as a social scientist is faced with the question: in what cultural or social space could such an alternative ethic develop? Whereas Horkheimer identifies that space as the family, specifically as the maternal sphere, Bauman identifies it only through cryptic and largely unexplained references to a "primordial," "primeval," or "presocial" experience of "being with others." "Responsibility being the existential mode of the human subject," he explains, "morality is the primary structure of the intersubjective relation in its most pristine form.... The substance of morality being a duty towards the other (as distinct from an obligation) and a duty which precedes all interestedness-the roots of morality reach well beneath societal arrangements, like structures of domination or culture." ${ }^{14}$ Because Bauman completely overlooks the history of gender relationships, he fails to acknowledge the culturally-constructed association of the sphere of the private, particular, and intimate with women and the family.$^{15}$ For the human individual, moreover, the original (that is, "primordial" or "primal" or "presocial") experience of unconditional love, proximity, and responsibility occurs in this female-identified sphere, through the motherchild relationship. ${ }^{16}$

Despite Bauman's gender-neutral language, his view of ethics and history, I would submit, is gendered in much the same way as Horkheimer's. In fact, by identifying the starting-point of his inquiry as his wish to understand the life experiences of his wife, Janina, a Holocaust survivor, Bauman symbolically locates the origin of his own ethical insights in the female and familial sphere. ${ }^{17}$ Both Bauman and Horkheimer in effect identify the realm of normative rationality with values stereotyped by Western culture as female or motherly. And both place this "female" realm outside of history, in a disempowered private sphere or in a primitive layer of the psyche that is not yet integrated into adult consciousness.

The same unacknowledged association of the realm of normative reason with women and with maternal influence is curiously prevalent in recent

14. Bauman, Modermity, 183.

15. Cf. Joan B. Landes, "The Public and the Private Sphere: A Feminist Reconsideration," in Feminists Read Habermas: Gendering the Subject of Discourse, ed. Johanna Meehan (New York, 1993), 91-116.

16. Cf. Axel Honneth, "The Other of Justice: Habermas and the Ethical Challenge of Postmodernism," in The Cambridge Companion to Habermas, ed. Stephen K. White (Cambridge, 1995), 289-324. "Genetically speaking, however, the experience of this moral principle precedes the encounter with all other moral points of view because... it stands at the beginning of the child's developmental process. Indeed, it may be the case that a sensorium for what can be called, in an unrestricted sense, equal treatment can only be developed in the first place if one's own person has had the experience of unlimited care at some time" (p. 318).

17. Bauman, Modernity, vii. 
studies of the Holocaust. Although Christopher Browning and Daniel Goldhagen never mention gender as an issue, they in fact give it a rather important role in their interpretations of the crimes of Police Battalion 101. Readers of both authors' books will remember that an officer of the battalion, the newlywed Captain Julius Wohlauf, brings his pregnant young wife Vera to Poland, where she observes a ghetto clearing. The very different images of Frau Wohlauf given by the two historians suggest that they see her chiefly as a symbolic figure representing the men's moral values, as each interprets them. Browning, who believes that at least some of the men had moral and emotional objections to their grisly task, pictures her as a "good woman," "clearly visible in her dress on the marketplace, watching the events at close range." 18 Goldhagen, who asserts that the men sadistically enjoyed their work, shows her as a "bad woman," equipped with the instruments of sadism: "Frau Wohlauf... probably carried that symbol of domination, a riding crop." 19 Both historians note that Wohlauf's comrades were outraged at Vera's presence, and thought it very inappropriate. Browning interprets this objection as evidence that the men "could still feel shame." Goldhagen, on the contrary, argues that the men did not, in fact, feel shame and adduces as evidence the fact that there were other female observers to whom the men did not object. Both of these accounts are based on the assumption that women (presumably of the privileged ethnic group) are respected by men as bearers of maternal authority, capable of inspiring shame; failure to feel shame in the presence of such women thus indicates utter shamelessness. In both accounts, Frau Wohlauf functions more as a symbolic figure onto whom male guilt and nostalgia (or, in the words of Klaus Theweleit "Männerphantasien" 20 ) are projected than as a historical actor herself, for neither historian extends his central concern with the motivation and responsibility of the men to this female participant.

Therefore the task of feminist scholarship has been to restore women to history by presenting them not as symbols but as subjects who, despite their disadvantaged status, made choices and bore moral responsibility. An important question in this historical inquiry must be the relationship of women to what Bauman and Horkheimer have called the culture of instrumental rationality. Did the Nazi regime place women of the dominant ethnic group in a separate sphere, identified with a traditional, even

18. Christopher Browning, Ordinary Men: Reserve Police Battalion 101 and the Final Solution in Poland (New York, 1993), 93.

19. Daniel Jonah Goldhagen, Hitler's Willing Executioners: Ordinary Germans and the Holocaust (New York, 1996), 242.

20. Klaus Theweleit, Male Fantasies, vol. 1, Women, Floods, Bodies, History, trans. Stephen Conway (Minneapolis, 1987). 
"reactionary" domestic ideology and isolated from the male-dominated public world? Or did Nazi policies actually encourage the erosion of public-private boundaries, so that women participated more fully in the public sphere? And what do both hypotheses imply for the central question-the responsibility of women as perpetrators and bystanders to the Holocaust?

Any analysis of the meaning of modernity to women must distinguish between normative and instrumental rationalization. The normative values of feminism, derived directly from the Enlightenment, center on the equality of women with men, meaning their right to equal respect and power in all aspects of culture and society. The inclusion of women in male-dominated professional and bureaucratic structures has sometimes been a means toward this end, and modern states, including the National Socialist state, have often turned feminist aspirations to their own advantage by offering to selected women various vocational and professional opportunities. But this form of modernization need not serve the normative end of gender equality - in fact, often it further instrumentalizes women in the service of male authority-and it thus cannot be regarded as a feminist end in itself.

To turn to the now substantial body of feminist historiography on women under National Socialism, what can be said about the modernization of gender and its implications for female responsibility? Among the first histories of women under National Socialism were two pioneering works in English, both dating from the 1970 s, by Jill Stephenson and Leila Rupp. ${ }^{21}$ Both historians present Nazi norms of feminine behavior (for "German" women, of course) as an inconsistent mixture of tradition and modernity. Stephenson cites the conflict between official glorification of domesticity and the advancement of women in many professions. ${ }^{22}$ The regime's lack of success in mobilizing women for wartime industrial work is interpreted by Rupp as a sign that many women responded skeptically to the regime's propaganda. ${ }^{23}$ Both authors, though stressing the involvement of many women in Nazi organizations, portray women in general as more distant than their male compatriots from the regime. Neither author specifically addresses the responsibility of women, as a group or individually, for the Holocaust.

Many of the first German works of feminist scholarship, dating from the 1980 s, presented women chiefly as victims of the regime rather than active participants in it. Historians such as Renate Wiggershaus, Annette

21. Jill Stephenson, Women in Nazi Society (New York, 1975); Leila Rupp, Mobilizing Women for War: German and American Propaganda, 1939-1945 (Princeton, 1978).

22. Stephenson, Women in Nazi Society, 185-99.

23. Rupp, Mobilizing Women, 167-81. 
Kuhn, and Valentine Rothe tended to see in the Nazi period chiefly another example of the oppression of women throughout history. The regime, they asserted, excluded women from professional opportunities, burdened them with unwanted pregnancy, consigned them to domestic servitude, and sought in all ways to reverse the achievements of feminism. ${ }^{24}$ "With National Socialism, for the first time a regime made the gendered division of labor into a major aspect of its power base," states an article in a feminist reference work published during this era, which makes no mention of women's role as perpetrators of genocide. ${ }^{25}$ Some of these works acknowledge and discuss the involvement of some women in National Socialism, as political functionaries, wives of Nazi officials, workers, or concentration-camp guards. But sometimes even the most obviously guilty perpetrators appear partly as victims. "These skimpy facts about her life," Renate Wiggershaus writes of the concentration-guard Hildegard Lächert,

suggest to us why Hildegard Lächert turned into "bloody Brygida." Certainly, as an illegitimate child, she was unloved; certainly she was under stress when she became pregnant at eighteen. And certainly neither in the BDM nor in the National Socialist women's organization did she gain the kind of human friendship, recognition, even love that she would have needed for her life. ... Did Hildegard Lächert try to relieve her own misfortune, her own pitiful, shabby existence by bringing unhappiness to others, hating them, and making their life not worth living? ${ }^{26}$

Soon other feminist historians of the 1980s, while still accepting the same basic identification of Nazism with reactionary domestic ideology, vigorously disputed this picture of women as passive dupes or victims. In her widely-cited book, Mothers in the Fatherland, Claudia Koonz claims that the regime's policies, which according to her glorified motherhood and gender difference, did not oppress but rather empowered "German" women by making them privileged members of the racial community. She argues against the conventional identification (also advanced by Horkheimer) of motherly love with humanitarian values, claiming that

24. Renate Wiggershaus, Frauen unterm Nationalsozialismus, (Wuppertal, 1984), 152. Other examples of early historiography are: Annette Kuhn and Valentine Rothe, Frauen im deutschen Faschismus, 2 vols. (Düsseldorf, 1984); Rita Thalmann, Etre femme dans le troisième Reich (Paris, 1981). A full summary and discussion of this literature is: Dagmar Reese and Carola Sachsse, "Frauenforschung und Nationalsozialismus: Eine Bilanz," in Töchter Fragen: NS Frauengesihichte, ed. Lerke Gravenhorst and Carmen Tatschmurat (Freiburg im Breisgau, 1990), 73-106.

25. Brigitte Bruns, "Nationalsozialismus," in Frauen-Handlexicon: Stichworte zur Selbstbestimmung, ed. Johanna Beyer, Franziska Lamott, and Birgit Meyer (Munich, 1982), 203-8.

26. Wiggershaus, Frauen unterm Nationalsozialismus, 103. 
German mothers affirmed the racial superiority of their own offspring and thus "made possible a murderous state in the name of concerns that they emphasized as motherly."27 Though she condemns Nazi stereotypes of gender difference and maternal nature as reactionary, Koonz finds many elements of modernity in the position and behavior of German women. For instance, she implicates the German feminist movements of the Weimar period, many of which supported some version of "separate spheres" ideology and advocated welfare measures for mothers, in preparing the way for National Socialism. Koonz sees the home as a site of collaboration rather than of potential resistance. The separation of the private from the public sphere, she charges, made the family a refuge for male perpetrators, who could find solace and the illusion of their own normality in an atmosphere of "ersatz goodness." ${ }^{28}$ Despite the fact that only a small number of women were directly involved, Koonz attributes to "German" women as a group a central role in genocide; "motherly love in its separate sphere, far from immunizing women against evil, fired women's dedication to the Führer's vision of an 'Aryan' future." 29

A very different view of the relationship of Nazi ideology and traditional domesticity has been advanced in the many works of the historian Gisela Bock. Bock's pioneering book on compulsory sterilization, published in 1986, denies that National Socialism truly favored domesticity, motherhood, or traditional doctrines of gender difference. Instead, Bock argues that the National Socialist state was distinguished from other contemporary societies less by its pronatalism (which resembled that of other countries) than by its antinatalism, realized through policies such as compulsory sterilization and eugenic abortion. Although in principle also similar to those of other states, these policies were in practice carried out with unparalleled energy and ruthlessness. ${ }^{30}$ Bock thus vigorously denies that National Socialism encouraged or honored motherhood. ${ }^{31}$ Neither, she argues, did the Nazis stress traditional femininity or gender difference in other areas of life. Bock points out that the percentage of women gainfully employed in Germany was similar to the percentage in other Western countries, and that most of the regime's initial attempts to deny educational and employment opportunity to women were progressively

27. Claudia Koonz, Mothers in the Fatherland: Women, the Family, and Nazi Politics (New York, 1987), 5.

28. Ibid., 420.

29. Ibid., 14.

30. Gisela Bock, Zwangssterilisation im Nazionalsozialismus: Studien zur Rassenpolitik und Frauenpolitik (Opladen, 1986), 461-64.

31. But for an opposing opinion see Ute Frevert, Women in German History: From Bourgeois Emancipation to Sexual Liberation, trans. Stuart MacKinnon-Evans (Oxford, Hamburg, New York, 1988), 236-38; Frevert emphasizes the importance of pronatalist measures. 
abandoned as the mobilization of men created the necessity for a skilled female labor force. Women's childbearing patterns resembled those of other Western societies, and prohibitions against abortion (until wartime) were not more severe than those elsewhere. ${ }^{32}$

Rejecting earlier identifications of Nazism with a reactionary and domestic view of womanhood, Bock thus claims that the regime encouraged certain aspects of modernization. From the labor-force status of modern women workers, integrated but unequal, she derives their responsibility for genocide. Women killers, such as concentration-camp guards, social workers, physicians, and others were working women, lured into maledominated organizations through the promise of high wages and aspiring to imitate men. For Bock, female guilt (in this and presumably in other cases) lay in women's entry into the public, male sphere. ${ }^{33}$ Though including housewives in the collective responsibility of the German nation, Bock insists that the private sphere of motherhood and family life was relatively uninvolved in the crimes of the state, and could even become a site of resistance, as when women defended themselves against compulsory sterilization by invoking the importance of motherhood and nurture in their lives. ${ }^{34}$

Despite their differences, both Bock and Koonz share the assumption (also shared by the Frankfurt School) that private and public spheres, and female and male roles, were separate and different. But this assumption too has been called into question by the research of the $1990 \mathrm{~s} .{ }^{35}$ For example, Gabriele Czarnowski investigates Nazi family policies, showing the extent to which the regime (far from affirming separate spheres) broke down public-private boundaries and instrumentalized the family in the service of political norms of productivity, racial selection, and ideological conformity. In her analysis of the penetration of the family by the state, Czarnowski builds on the insights of the Frankfurt School, but whereas the Frankfurt theorists emphasized the role of the father in promoting authoritarian values, Czarnowski focuses on female mothering and domestic

32. Gisela Bock, "Gleichheit und Differenz in der nationalsozialistischen Rassenpolitik," Geschichte und Gesellschaft 19 (1993): 279-81.

33. Ibid., 309-10. For a view of women's roles in administering euthanasia, see Henry Friedlander, The Origins of Nazi Genocide: From Euthanasia to the Final Solution (Chapel Hill, 1995), 231-32.

34. Gisela Bock, "Die Frauen und der Nationalsozialismus: Bemerkungen zu einem Buch von Claudia Koonz," Geschichte und Gesellschaft 15 (1989): 569. For Koonz's response to this review see Claudia Koonz, "Erwiderung auf Gisela Bocks Rezension von "Mothers in the Fatherland'," Geschichte und Gesellschaft 8 (1992): 394-99.

35. For a very useful summary of recent literature on women and National Socialism see Adelheid von Saldern, "Victims or Perpetrators? Controversies about the Role of Women in the Nazi State," reprinted in Nazism and German Society: 1933-1945, ed. David Crew (London and New York, 1994), 141-65; see also Reese and Sachsse, "Frauenforschung." 
activities. ${ }^{36}$ Newer studies also avoid global statements about the status of "women," or of "German" women, and focus on specific groups.

The results of this research in general confirm Bock's assertion that Nazi ideas of female behavior were in many ways modern, at least in the sense that girls and women were integrated into some previously malestereotyped activities and rituals. Research on women's work in the SS and as concentration-camp guards shows the eagerness with which some women accepted official norms of toughness. ${ }^{37}$ Dagmar Reese's study of girls in the BDM describes a comradely, athletic, and male-imitative rather than a conservatively domestic ideal of female behavior. ${ }^{38}$ Likewise, a recent article by Elizabeth $\mathrm{H}$. Tobin and Jennifer Gibson concludes that many young women of this era were much less impressed by the official glorification of motherhood and domesticity than by the possibilities for professional and career development offered by the regime. These findings, based on women's memories as recorded through oral history, challenge Leila Rupp's conclusion that German women took a skeptical view of the regime's propaganda. Tobin and Gibson demonstrate that some women were uncomplaining and even enthusiastic participants in the compulsory year of service required by the regime and in war-related work. ${ }^{39}$

The newest research, therefore, tends to debunk the generalization (put forward by the historians Michael Burleigh and Wolfgang Wippermann among others) ${ }^{40}$ that Nazi policy toward women can be summed up by the cliché of "Kinder, Küche, Kirche," and shows that women, too, participated in the culture of instrumental rationality. But their participation did not make that culture less male-dominated. ${ }^{41}$ The fact that certain career opportunities were open to women under National Socialism (in

36. Gabriele Czarnowski, Das kontrollierte Paar: Ehe und Sexualpolitik im Nationalsozialismus (Weinheim, 1989).

37. See for example Claus Füllberg-Stolberg, Martina Jung, Renate Riebe, Martina Scheitenberger, eds., Frauen in Konzentrationslagem: Bergen-Belsen, Ravensbrück (Bremen, 1994). See also Gudrun Schwarz, "Verdrängte Täterinnen: Frauen im Apparat der SS (1939-1945)," in Nach Osten, ed. Theresa Wobbe (Frankfurt, 1992), 197-227. An early and still very useful article is Sybil Milton, "Women and the Holocaust: The Case of German and German-Jewish Women," in When Biology Became Destiny: Women in Weimar and Nazi Germany, ed. Renate Bridenthal, Atina Grossmann and Marion Kaplan (New York, 1984); reprinted in Carol Rittner and John K. Roth, eds., Different Voices: Women and the Holocaust (New York, 1993), 213-49.

38. Dagmar Reese, Straff aber nicht stramm, herb, aber nicht derb: Zur Vergesellschaftung von Mädchen durch den Bund deutscher Mädel im sozialkulturellen Vergleich zweier Milieus (Weinheim, 1989).

39. Elizabeth H. Tobin and Jennifer Gibson, "The Meanings of Labor: East German Women's Work in the Transition from Nazism to Communism," Central European History 28, no. 3 (1995): 301-41.

40. Michael Burleigh and Wolfgang Wippermann, The Racial State: Germany 1933-1945 (Cambridge, 1991), 242.

41. Bock, Zwangssterilisation, 207. 


\section{THE HOLOCAUST $\&$ THE MODERNIZATION OF GENDER}

many ways similar to those available to women in other Western societies), and that women took advantage of these opportunities, has led some historians to assert or to imply that the regime actually supported feminist aspirations. To cite only one example, Götz Aly and Susanne Heim preface a short section on the participation of female researchers in Nazi racial science with the snide heading, "Emancipation." 42 But here we must make the important distinction between normative and instrumental rationality. Advancement in careers does not necessarily fulfill the normative goal of feminism, the equal power and value of women and men in all areas of life. In this case, women's energy and ambition was instrumentalized in the service of one of the most brutally male-supremacist regimes ever known to history. The regime suppressed all feminist organizations and, although sponsoring large party-affiliated women's organizations, gave them no role in important policy decisions. The subordination of women in politics and in public institutional structures was expressly intended to discredit the values that the Nazis stereotyped as feminine. An excellent example is provided by Doris Bergen, who describes the efforts of the Nazi-identified "German Christian" movement both to reduce the actual power of women in the church and to create a "manly" Christianity free of traditional Christian values of compassion and concern for individuals. ${ }^{43}$

The Nazis' destruction of feminist movements was of course only one aspect of their broader effort to destroy all forms of difference, whether political, cultural, or "racial." The suppression of democracy and enforcement of conformity was a necessary, though of course not a sufficient, precondition for the horrors of war and genocide that followed. This history of suppression is overlooked by both Bauman and Horkheimer, whose sweeping and undifferentiated indictment of Western culture implies that the subservience of Western intellectuals to the claims of the totalitarian state was universal and unquestioned. In fact, the Western tradition has included many alternative and dissenting voices, those of feminists among a multitude of others. It is curious that Bauman, so critical of the universalizing tendencies of Western thought, does not himself attend to the many voices-including in this case those of religious dissenters, socialist and labor movements, and many artists and writers as well as feministsthat must be silenced in order to make reason subservient to power.

Because they do not acknowledge the importance of dissent within the tradition of Western rationality, theorists such as Horkheimer and Bauman

42. Götz Aly and Susanne Heim, Vordenker der Vernichtung: Auschwitz und die deutschen Pläne für eine neue europäische Ordnung (Frankfurt, 1995), 198.

43. Doris Bergen, Twisted Cross: The German Christians in the Third Reich (Chapel Hill, 1996). 
can envisage no basis for change. Horkheimer, who looks toward the recovery of the normative reason of the Enlightenment as "the redemption of the hopes of the past," ${ }^{44}$ has no clear view of the means to this end, nor even of the end itself. ${ }^{45}$ Bauman, who does not acknowledge even the potential for a critical reason, is left floundering in his own uncertainty. As we have seen, he turns to Lévinas for a postmodern alternative to the malady that he defines as distinctively modern, the tendency to claim universal validity for philosophical and political systems that override and annihilate the individual. Along with Lévinas, Bauman insists that the face-to-face proximity to the Other, and the resulting respect for the Other's unique individuality, are the sources of a morality of which individual responsibility and caring are the transcendental values. But he can explain neither why this ethic of empathy has been disempowered in Western culture, nor what forms of social change would be needed in order to empower it.

By failing to recognize how all such ethical values are and have been shaped by cultural constructions of gender, Bauman omits an essential historical dimension of his argument. Certainly one important historical precondition for what Bauman characterizes as "the great divide which was to become the trademark of modern living ... between reason and emotion" 46 was the separation of spheres that identified the former with a masculine and public sphere, and the latter with a feminized and private sphere. And one reason for the disempowerment of the ethical values of caring, empathy, and face-to-face intimacy in Western culture has been the subordination of the women to whom such values have been culturally attributed.

The relationship of gender relations to ethics has been extensively explored by feminist theorists such as the psychologist Carol Gilligan, whom Bauman fails even to cite. In her controversial and much-discussed book, In a Different Voice, Gilligan identifies a characteristically female "ethic of care." Women, she demonstrates, typically derive their ethical decisions less than men from impersonal and rule-oriented criteria, and more from a flexible awareness of the possible consequences of any given decision for the other human beings affected. Gilligan and other feminist theorists, though they have often been accused of biological essentialism, do not attribute this ethical outlook to female biology. Rather, they argue that the status of women as "different" or "other," as outsiders to male-supremacist power structures, provides them with a standpoint from which to perceive

44. Horkheimer and Adorno, Dialectic of Enlightenment, xv.

45. Cf. Rumpf, "Mystical Aura," 311.

46. Zygmunt Bauman, Life in Fragments: Essays in Postmodem Morality (Oxford, 1995), 258. 


\section{THE HOLOCAUST \& THE MODERNIZATION OF GENDER}

the highly unjust consequences that often result from conventional conceptions of justice. Unlike Horkheimer and Bauman, feminist theorists do not identify this "different" ethical consciousness with a presocial or immature phase of human development, with fantasies about the "paradise of childhood," or with a private sphere separated from public and political concerns. They assert that it is fully as valid and empowering as the dominant model. ${ }^{47}$

Building upon Gilligan's basic insights, many feminist theorists such as Seyla Benhabib and Iris Marion Young have shown how conventional Western conceptions of justice, which place abstract rationality above human concern, have perpetuated male supremacy in the guise of universal reason. These theorists do not self-righteously proclaim the moral superiority of conventionally "female" values. Rather, they search for an approach to ethics that combines concerns for justice and for care. ${ }^{48}$ "Theoretically, the distinction between justice and care cuts across the familiar divisions between thinking and feeling, egoism and altruism, theoretical and practical reasoning," Gilligan writes. "Since everyone is vulnerable both to oppression and to abandonment, two moral visions-one of justice, one of care-recur in human experience. The moral injunctions, not to act unfairly toward others, and not to turn away from someone in need, captures these different concerns." 49

By pointing to the importance of feminist theory to our understanding of the ethical issues raised by Bauman's meditation of the Holocaust, I do not imply that this or any other contemporary theoretical project can provide facile answers to the most difficult and intractable questions raised by recent history. However, the development of feminist theory itself can shed light on one of Bauman's central concerns, the origin of critical or normative reason. For, as the history of the Enlightenment suggests, critical reason does not arise from disinterested intellectual speculation, but from the concrete historical situation of persons and groups who are excluded from power and are thus in a position both to perceive and to unmask the dominant ideology that upholds it. The Other of Bauman's

47. Carol Gilligan, In a Different Voice: Psychological Theory and Women's Development (Cambridge, Mass., 1982); Seyla Benhabib, "The Debate over Women and Moral Theory Revisited," in Meehan, ed., Feminists Read Habermas, 231-46.

48. Seyla Benhabib, "The Generalized and the Concrete Other: The Kohlberg-Gilligan Controversy and Feminist Theory," in Feminism as Critique, ed. Benhabib and Comell, 77-96; Iris Marion Young, "Impartiality and the Civic Public: Some Implications of Moral and Political Theory," in Feminism as Critique, 56-76; and Seyla Benhabib, Situating the Self: Gender, Community and Postmodernism in Contemporary Ethics (New York, 1992).

49. Carol Gilligan, "Moral Orientation and Moral Development," in E. F. Kittay and Diane T. Myers, Women and Moral Theory (Totowa, 1987), 20. Quoted in Seyla Benhabib, "The Debate over Moral Theory Revisited," 191-92. 
and Lévinas's discourse becomes at certain historical moments not simply an accusing presence, but a challenging voice. Among such dissenters, feminists of our own time have played a major role in developing just that critique of the relationship of knowledge to power that has been so important recently to Holocaust studies as well as to other areas of inquiry.

In the investigation of the connections between the construction of gender and the cultural preconditions for the Holocaust, certain directions of inquiry will be important in the future. Nazi constructions of masculinity - which by contrast to corresponding constructions of femininity have received little attention-require more systematic examination. As Adelheid von Saldern sensibly remarks, the investigation of norms of both male and female behavior as practiced by specific groups of perpetrators and bystanders will give a more differentiated picture of gender construction as it shaped, and was shaped by, Nazi society. ${ }^{50}$ An important step in that direction is Doris Bergen's study of the German Christian Church, which examines how Nazi norms of masculinity and femininity influenced this group's religious ideas and practice. ${ }^{51}$ The comparative perspective is also important. Most of the social, economic, and cultural roles allotted to women in Nazi Germany were not distinctive to that society, but were similar to those held by women in other contemporary Western societies, whose rates of gainful employment, child-bearing, and involvement in state bureaucracies were similar to those of their German counterparts. How, then, can we make the involvement of women in the state's "culture of instrumental rationality" a cause of the Holocaust, acknowledged to be a unique event? For that matter, can we really say that the spirit of technological rationality and bureaucratic efficiency was so much more prevalent among German than among other Western men as to account, as Bauman implies, for the singularly German development of National Socialism? If the Enlightenment did, indeed, furnish the intellectual preconditions for fascism and genocide, then why did the Western cultures which were much more deeply influenced by the Enlightenment than Germany-such as France or the United States-produce no similar phenomena $?^{52}$ The early example of comparative history created by Leila Rupp's study of the mobilization of American and German women during the Second World War provides a precedent for future cross-cultural studies of both male and female activities. ${ }^{53}$

In conclusion, I will return to Bauman's central focus: the split in the Western psyche between instrumental and normative rationality. Bauman

50. von Saldern, "Victims or Perpetrators?"

51. Bergen, Twisted Cross.

52. I thank Kenneth Barkin for suggesting this question.

53. Rupp, Mobilizing Women for War. 
implies that only the erasure of these boundaries, resulting in the integration of technological and bureaucratic efficiency with human responsibility, will create a new ethical consciousness. I would suggest that one means to this end would surely be the integration of the male and female spheres, so that men cannot escape the responsibility of human caring, nor women the responsibility of public decision-making and action. This hope seems to me not to be in conflict with the heritage of the Enlightenment, but on the contrary, to continue the tradition originated by Mary Wollstonecraft, Theodor Gottlieb Hippel, the Marquis de Condorcet, and many others. "Women I allow may have different duties to fulfil," wrote Wollstonecraft in 1792, "but they are human duties, and the principles that should regulate the discharge of them, I sturdily maintain, must be the same." 54

UNIVERSITY OF LOUISVILLE

54. Mary Wollstonecraft, A Vindication of the Rights of Woman, ed. Carol H. Poston (New York, 1988), 51. 